\title{
Acrylamide Formation Potential of Organically and Conventionally Grown Cereals
}

\author{
Falko Stockmann ${ }^{1 *}$, Ernst Albrecht Weber ${ }^{1}$, Benjamin Mast ${ }^{1}$, Pat Schreiter ${ }^{2}$ Nikolaus Merkt ${ }^{1}$, \\ Wilhelm Claupein ${ }^{1}$, Simone Graeff-Hönninger ${ }^{1}$ \\ 1 Institute of crop science, University of Hohenheim, D-70599, Stuttgart, Germany \\ 2 Chemisches und Veterinäruntersuchungsamt Stuttgart, Schaflandstraße 3/2, D-70736 Fellbach, Germany \\ * Correspondence: letsch.stockmann@gmail.com; Tel.: +49-9420-8010239
}

\begin{abstract}
As bakery products contribute considerably to the daily intake of the carcinogen acting substance acrylamide (AA), the aim of this study was to evaluate the impact of the cropping system (conventional vs. organic farming) on AA precursor levels of free asparagine (Asn) across different cultivars of the cereal species, namely winter wheat (Triticum aestivum), winter spelt (Triticum aestivum ssp. spelta) and winter rye (Secale cereale) with simultaneous consideration of gained grain yields and flour qualities. For this purpose, orthogonal field trials were established at two sites in Southwest Germany over two growing seasons (2006-2007 and 2007-2008). The results indicated a significant impact of the cropping system on free Asn contents. Across all species, free Asn contents in the flour were $26 \%$ lower under organic compared to conventional farming. The impact of the cropping system on individual cultivars was obvious with a maximum reduction in free Asn contents of 50 \% (e.g. for cultivars Ludwig, Privileg, Capo) if organically produced. For spelt, a significant impact of the cropping system was only found in 2008 with a reduction in free Asn of up to $25 \%$ if organically produced. Across both cropping systems, cultivar Franckenkorn reached the lowest levels of free Asn. For rye, a significant impact of the cropping system was observed only in 2007 with $33 \%$ higher Asn amounts in the conventional cropping system. Independent of the cropping system, rye reached the highest levels of free Asn followed by wheat and spelt. Across both cropping systems, species and cultivars, the amount of free Asn correlated with the AA content in heated flour with $\mathrm{R}^{2}=0.63^{* * *}$. Furthermore, the results indicated that lower AA contents in bakery products can be achieved by proper selection of species (e.g. $66 \%$ lower if rye is replaced by wheat) and cultivars. With an appropriate choice of the cultivar, a reduction of up to $65 \%$ was possible within wheat, along with a reduction of $44 \%$ within spelt and $12.5 \%$ within rye. In summary, the results indicated that organically produced wheat especially offers the opportunity to significantly lower the AA potential of bread and bread rolls by the choice of raw materials low in free Asn.
\end{abstract}

Keywords: Acrylamide, Free Asparagine, Cropping Systems, Organic, Conventional, Agriculture, Cereals, Species, Cultivars

\section{Introduction}

Due to a current announced regulation of the European Commission [10] food industry and gastronomy face the challenge of establishing immediate mitigation strategies and benchmark levels for acrylamide (AA).

More than 15 years after the first findings of the food-borne toxicant AA in starch-rich heated foods, the dietary intake of AA is now seriously regarded to potentially increase cancer risk for humans [24]. Therefore, AA in foodstuffs should be minimized to a level as low as reasonably achievable.

Since 2002, it was successfully shown that AA is formed during a thermal treatment of carbohydrate rich food like cereals and potatoes [33, 40], where 'reducing sugars' (mostly glucose and fructose) react with the amino acid free asparagine (Asn) within the Maillard reaction [14]. While reducing sugars are the limiting precursor in heated potato products [1], free Asn is the limiting 
precursor for processed cereal based products [8, 13, 42, 47]. Although strongly heated potato products can contain much more AA than cereal based products, foods like bread, rolls, biscuits and crisp bread contribute to about 25 to $45 \%$ of the dietary AA intake in Germany [17]. This is mainly due to the high daily per capita consumption of bread of almost $240 \mathrm{~g}$ [9].

It has been shown, that the amount of AA can be minimized by adjusting processing parameters such as $\mathrm{pH}$, heating temperature and time of heating, changing baking agents, as well as adding additives, or by elucidating the mechanistic pathways of AA formation and eliminating precursors or intermediates $[1,6,7,9,22,26,45]$.

Modification of recipes or processing conditions often led to significant reductions in AA levels of the final products. However, their applicability is restricted, because their use is often accompanied by negative effects on taste or quality of the final products or their use is simply too expensive. The used raw material, notably the Asn precursor content in cereal grains, plays an important role for the AA formation potential. Consequently, one alternative to reduce AA in the final product might be minimizing Asn contents in cereal grains by agronomic management.

Several studies showed that cereal species differ in their Asn levels and in consequence in their acrylamide formation potential. Rye usually has higher Asn levels compared to wheat and spelt [8, $12,13]$. Moreover, cultivars can differ considerably in their precursor content as shown by several studies $[8,11,12,13,43]$. Taeymans et al. [43] reported a 5-fold range for a variety of European wheat cultivars and Claus et al. [8] found a variability of Asn contents in nine German winter wheat cultivars of up to a factor of 3. Corol et al. [11] reported differences of 150 wheat genotypes analysed as wholemeal samples of almost 5 -fold. Thus, selection of suitable cultivars with low Asn contents is considered as a feasible way to minimize AA formation potential, although it has to be taken into account that environmental conditions (site-specific soil properties and climate) may alter Asn contents considerably $[12,13]$.

Fertilization is a key measure in crop production that increases yield and quality and affects Asn levels as well. Nitrogen amount and timing of application, as well as nitrogen form can affect Asn contents in wheat considerably [30,46]. Especially high nitrogen availability during grain filling leading to high crude protein contents is considered to increase free Asn levels significantly [46]. Postles et al. [36] found for rye that free Asn was influenced by variety and nitrogen supply. Moreover, sulphur deficiency can dramatically increase Asn contents and thus the AA formation potential [20,34]. Furthermore, fungicide application promoting leaf area duration and delaying senescence can reduce free Asn content in grains [30]. Further, environmental conditions given by different growing locations can highly change the level of free Asn within wheat genotypes [11].

However, most of the studies noted were accomplished for conventional crop production only. Thus, the question arose, if there might be a considerable difference between organic and conventional cereal production systems in their impact on AA precursor content and AA formation potential as organic farming uses different agronomic practices like nitrogen fertilization strategies and, to some extent, different cultivars are used. In a study by Springer et al. [39], the comparison of Asn contents of two organically and two conventionally produced rye cultivars revealed higher Asn contents in the organically produced rye, but no additional information about site, growing conditions and management were given. Preliminary studies of Stockmann et al. [41] reported an effect of the cropping system, as wheat cultivars grown under organic conditions showed a significantly lower amount of free Asn when compared to conventionally grown wheat cultivars. Further studies investigating the effect of organic versus conventional growing practice on yield, quality, and the latter AA content of cereal products have, to date, not been published.

With regard to the steadily rising demand for organically produced products in Germany and the association that organically produced foodstuffs are considered per se healthier than conventionally produced ones, filling this knowledge gap is essential.

Therefore, the main focus of this study was to compare different wheat, rye and spelt cultivars grown under conventional and organic farming conditions over two consecutive growing seasons regarding their free Asn content and AA formation potential under the consideration of yield and 
quality. Special emphasis was given towards analysing the impact of the cropping system on free Asn content and AA formation.

\section{Materials and Methods}

\subsection{Experimental sites}

To transfer results into practice and obtain realistic results under typical cropping conditions of each production system, field trials were installed at two different sites located $\sim 20 \mathrm{~km}$ away from each other. The sites are characteristic for organic and conventional farming procedures. This must be taken into account when interpreting the results. The field trial under conventional management was carried out over two consecutive growing seasons $(2006-2007 ; 2007-2008)$ at the experimental station Ihinger Hof, Renningen $\left(48^{\circ} 44^{\prime} \mathrm{N} 8^{\circ} 55^{\prime} \mathrm{E}\right.$; average annual temperature $8.3^{\circ} \mathrm{C}$; average annual rainfall $693 \mathrm{~mm}$ ) of the University of Hohenheim. The same trial was accomplished in parallel under organic management at the experimental station for organic farming of the University Hohenheim, Kleinhohenheim, Stuttgart $\left(48^{\circ} 44^{\prime} \mathrm{N} 9^{\circ} 12^{\prime} \mathrm{E}\right.$; average annual temperature $8.8^{\circ} \mathrm{C}$; average annual rainfall $700 \mathrm{~mm}$ ). Detailed data on temperature and rainfall during the seasons 2006-2007 and 20072008 for both sites are depicted in Table 1 .

Table 1: Temperature and rainfall during the experimental seasons 2006-2007 and 2007-2008 at the locations Ihinger Hof, Renningen and Kleinhohenheim, Stuttgart, both in South-West Germany)

\begin{tabular}{lllll}
\hline Location & \multicolumn{2}{l}{ Ihinger Hof (conventional) } & \multicolumn{2}{l}{ Kleinhohenheim (organic) } \\
2006/2007 & Temp. $\left({ }^{\circ} \mathbf{C}\right)$ & Rainfall $(\mathbf{m m})$ & Temp. $\left({ }^{\circ} \mathbf{C}\right)$ & Rainfall $(\mathbf{m m})$ \\
September & 16.3 & 50 & 17.4 & 59.2 \\
October & 11.9 & 74 & 12.9 & 80.0 \\
November & 7.1 & 22 & 7.8 & 25.2 \\
December & 3.4 & 22 & 4.0 & 31.2 \\
January & 4.4 & 49 & 5.0 & 22.2 \\
February & 4.4 & 69 & 5.2 & 102.0 \\
March & 5.3 & 50 & 6.5 & 80.2 \\
April & 12.2 & 1 & 13.7 & 0.2 \\
May & 14.1 & 104 & 15.0 & 142.0 \\
June & 17.7 & 107 & 17.7 & 140.8 \\
July & 16.9 & 69 & 17.8 & 91.0 \\
August & 16.4 & 64 & 17.3 & 69.0 \\
\hline Mean/Sum & 11.4 & 681 & 11.7 & 843.0 \\
\hline 2007/2008 & Temp. $\left({ }^{\circ} \mathbf{C}\right)$ & Rainfall $(\mathbf{m m})$ & Temp. $\left({ }^{\circ} \mathbf{C}\right)$ & Rainfall $(\mathbf{m m})$ \\
\hline September & 11.8 & 48 & 12.9 & 56.2 \\
October & 8.2 & 7 & 9.3 & 15.4 \\
November & 3.2 & 63 & 3.6 & 100.2 \\
December & 0.8 & 53 & 1.3 & 61.6 \\
January & 3.1 & 39 & 4.0 & 47.2 \\
February & 3.6 & 21 & 4.8 & 27.4 \\
March & 4.3 & 64 & 5.1 & 86.4 \\
April & 7.5 & 103 & 8.4 & 105.2 \\
May & 14.8 & 101 & 15.7 & 76.8 \\
June & 17.2 & 93 & 17.6 & 109.6 \\
July & 17.7 & 57 & 18.5 & 61.2 \\
August & 16.8 & 99 & 17.7 & 112.6 \\
\hline Mean/Sum & 9.1 & 748 & 9.9 & 860.0 \\
\hline
\end{tabular}


The field trials at Thinger Hof were carried out on loess derived soils 1 with soil textures of silt (2006-2007) and silty clay (2007-2008) with sugar beet as the previous crop for both years. $N_{\min }$ values at start of the vegetation period (end of March) in 2006 and 2007 in a soil depth of $0-90 \mathrm{~cm}$ were 2.4 and $31 \mathrm{~kg} \mathrm{NO}_{3}-\mathrm{N} \mathrm{ha}^{-1}$, respectively.

The soils at Kleinhohenheim were loess derived with a loamy soil texture with faba beans as the previous crop for both years. $\mathrm{N}_{\text {min }}$ values at start of vegetation period in 2006 and 2007 in a soil depth of $0-90 \mathrm{~cm}$ were 41.8 and $58.7 \mathrm{~kg} \mathrm{NO}_{3}-\mathrm{N} \mathrm{ha}^{-1}$, respectively.

\subsection{Experimental design}

Ten winter wheat, five winter spelt and five winter rye cultivars (Table 2), suitable for conventional, as well as for organic farming in Central Europe, were tested in a randomized complete block design (plot size $4 \times 6 \mathrm{~m}$ ) with three replicates. To avoid neighbouring effects between the different crop species due to differences in plant height, species were separated by a border plot with a width of $2 \mathrm{~m}$. Species groups were randomly placed in each block and within each species group cultivars were arranged randomly.

Table 2: Cereal species and cultivars tested in the field trials

\begin{tabular}{lll}
\hline Species & Cultivar & Quality grade* \\
\hline Winter wheat & Akteur & E \\
& Bussard & E \\
& Achat & E \\
& Privileg & E \\
& Capo & E \\
& Enorm (only at Ihinger Hof) & E \\
& Batis & A \\
& Naturastar & A \\
& Ludwig & A \\
& Astron & A \\
& Magnus & A \\
Winter spelt & Schwabenspelz & - \\
& Ceralio & - \\
& Oberkulmer & - \\
& Rotkorn & - \\
Finter rye & Franckenkorn & - \\
& Schwabenkorn & - \\
& Amilo & - \\
& Nikita & - \\
Recrut & Danko & - \\
& Pollino & - \\
& & -
\end{tabular}

*refers to the German quality classes. E-wheat: highest baking quality, A-wheat: high baking quality

\subsection{Experimental performance}

Primary tillage was done with a cultivator $(15 \mathrm{~cm}$ depth) at Ihinger Hof and with a mouldbord plough (25 cm depth) at Kleinhohenheim. Seed bed preparation was accomplished by a power harrow at both experimental sites.

Sowing was done for all species on 12/10/2006 and 09/10/2007 at Ihinger Hof and on 19/10/2006 and 17/10/2007 at Kleinhohenheim. Winter wheat and winter spelt were sown on both locations with a sowing density of 350 seeds $\mathrm{m}^{-2}$. Sowing density of winter rye was 300 seeds $\mathrm{m}^{-2}$. Row distance was $0.10 \mathrm{~m}$ at Ihinger Hof and $0.12 \mathrm{~m}$ at Kleinhohenheim. 
Nitrogen was applied as CAN (calcium ammonium nitrate: $13.5 \%$ Nitrate-N, $13.5 \%$ Ammonium-N) in the conventional trial. For winter wheat, total nitrogen amounts of 190 to $195 \mathrm{~kg}$ $\mathrm{N}$ ha ${ }^{-1}$ were applied in four to five rates according to the expected yield and the expected crude protein content (for details see Table 3). Winter spelt and winter rye cultivars were fertilized with 140 and $150 \mathrm{~kg} \mathrm{~N} \mathrm{ha}^{-1}$ in four rates (Table 3).

Table 3: Time and amount of the N-fertilization for the conventionally produced species

\begin{tabular}{|c|c|c|c|c|c|c|}
\hline \multirow{4}{*}{$\begin{array}{l}\text { Species/ } \\
\text { Quality class }\end{array}$} & \multicolumn{6}{|c|}{ Time and amount of N-Fertilization [kg $\left.\mathrm{N} \mathrm{ha}^{-1}\right]$} \\
\hline & $\mathrm{N}_{\text {Total }}$ & Nstart of Veg. & $\mathrm{NeC}_{\mathrm{E} 1 / 32}$ & $\mathrm{~N}_{\text {EC37/39 }}$ & $\mathrm{N}_{\mathrm{EC} 49 / 51}$ & NeC59/61 \\
\hline & & 08/03/2007 & 02/04/2007 & 07/05/2007 & $24 / 05 / 2007$ & $31 / 05 / 2007$ \\
\hline & & 06/03/2008 & $28 / 04 / 2008$ & $28 / 05 / 2008$ & 02/06/2008 & $10 / 06 / 2008$ \\
\hline E-Wheat & 190 & 40 & 40 & 30 & 50 & 30 \\
\hline A-Wheat & 195 & 55 & 40 & 50 & 50 & - \\
\hline Spelt & 140 & 40 & 40 & 30 & 30 & - \\
\hline Rye & 150 & 70 & 40 & - & 40 & - \\
\hline
\end{tabular}

In the organic trial, all species were supplied with $100 \mathrm{~kg} \mathrm{~N} \mathrm{ha}^{-1}$ by liquid cattle manure $\left(100 \mathrm{~m}^{3}\right.$ ha $^{-1}: 1 \mathrm{~kg} \mathrm{~N} \mathrm{~m}^{-3}$, total nitrogen content, $4 \%$ dry matter) in two rates a $50 \mathrm{~m}^{3} \mathrm{ha}^{-1}$ at start of vegetation and at start of stem elongation.

Growth regulators (Chlorcholinchloride and Trinexapac-ethyle), herbicides (Atlantis $®$ : Iodsulfuron-methyl-sodium, Mefenpyr-diethyl, Mesosulfuron-methyl, Concert ${ }^{\circledR}$ : Metsulfuronmethyl, Thifensulfuron-methyl, Primus: Florasulam), fungicides (Juwel top ${ }^{\circledR}$ : Fenpropimorph, Epoxiconazol, Kresoxim-methyl) and insecticides (Bulldock®: beta-Cyfluthrin) were broadcast as needed in the conventional trial. No pesticides and no growth regulators were applied in the organic trial.

In 2008, the organic field was harrowed twice (31/03/2008 and 26/05/2008) to control weeds. Due to low weed densities, harrowing was omitted in the year prior.

Harvest was accomplished by a Hege 180 plot combine harvester (Hege, Eging am See, Germany) after grains had reached a dry matter content of $85 \%$.

\subsection{Yield}

Grain yield of the cereal species and cultivars was determined by weighing the plot yield. Grain samples were dried at $105{ }^{\circ} \mathrm{C}$ for $24 \mathrm{~h}$ to determine grain moisture. Grain yields given refer to $86 \%$ dry matter content.

\subsection{Flours}

For the determination of quality parameters, the determination of the AA precursor content free Asn and the AA formation potential, grain samples were milled on a laboratory mill (Quadrumat Junior, Brabender, Duisburg, Germany). Ash content of flours was about $0.5 \%$ of flour DM. Flour moisture was calculated from the weight loss before and after drying of about $5 \mathrm{~g}$ flour at $105^{\circ} \mathrm{C}$ for $24 \mathrm{~h}$.

\subsection{Crude protein content}

Total grain nitrogen content was determined by Near-Infrared-Spectroscopy (NIRS, NIRS 5000, FOSS GmbH Rellingen, Deutschland). Calibration samples were analysed according to the Dumas Method [15] using a Vario Max CNS analyzer (Elementar, Hanau, Germany). The analysed final nitrogen content was multiplied by a factor of 5.7 [44] for wheat samples and 6.25 for spelt and rye samples. 


\subsection{Zeleny's sedimentation test}

Zeleny's sedimentation test was determined in wheat and spelt flours using $3.2 \mathrm{~g}$ flour according to ICC standard No. 116. The sedimentation values of the flours were adjusted to a $14 \%$ moisture basis.

\subsection{Free asparagin}

Free amino acids were extracted with either $2 \mathrm{~g}$ of wheat or spelt flour or $1 \mathrm{~g}$ of rye flour and were mixed with $8 \mathrm{ml}$ of $45 \%$ ethanol for $30 \mathrm{~min}$ at room temperature. After centrifugation for $10 \mathrm{~min}$ at room temperature with $4000 \mathrm{rpm}$ and $10 \mathrm{~min}$ at $10^{\circ} \mathrm{C}$ and $14000 \mathrm{rpm}$, the supernatant was filtered through a $0.2 \mu \mathrm{m}$ syringe filter and poured into vials. Asparagine analysis was performed using Merck - Hitachi HPLC components. The pre column derivatization with FMOC [29] was completely automated by means of an injector program. Subsequently, the derivatized Asn was separated on a LiChroCART Superspher RP 8 column $(250 \mathrm{~mm}$ x $4 \mathrm{~mm}$, Fa. Merck, Darmstadt) at a constant temperature of $45^{\circ} \mathrm{C}$. The fluorescence intensity of the effluent was measured at the excitation and emission maxima of 263 and $313 \mathrm{~nm}$.

\subsection{Acrylamide formation potential}

The AA formation potential of cereal flour was assessed according to the AA contents of $5 \mathrm{~g}$ flour in $250 \mathrm{ml}$ Erlenmeyer flasks after heating in an oven for $10 \mathrm{~min}$ at $200{ }^{\circ} \mathrm{C}$. Due to the complexity of the acrylamide analysis, sample size was reduced to an overall number of 28 samples (6 winter wheat, 4 winter spelt and 4 winter rye samples from two investigation years).

Sample preparation was accomplished according to the test procedure 200L05401 [48] of the Chemische und Veterinäruntersuchungsamt (CVUA) Stuttgart.

After cooling down to ambient temperature, $100 \mathrm{ml}$ of bidestilled water and $100 \mu \mathrm{l}$ of $\mathrm{D}_{3}$ Acrylamide were added as an internal standard to the heated flour samples in the Erlenmeyer flasks. To completely extract acrylamide from the flour, samples were put in an ultrasonic bath for 10 minutes at $40{ }^{\circ} \mathrm{C}$. After adding $1 \mathrm{ml}$ of Carrez I and II to each of the samples, and shaking the flasks thoroughly, the samples were filtered using folded filter paper to separate the colloids and flour particles from the aqueous solution. Subsequently, samples were cleaned up by a solid phase extraction in a vacuum chamber after preconditioning the cartridges by $10 \mathrm{ml}$ of bidestilled water and $10 \mathrm{ml}$ methanol. After sample clean-up about 1 to $2 \mathrm{ml}$ of the eluate from each sample was filled in an autosampler vial and was deep frozen $\left(-18^{\circ} \mathrm{C}\right)$ until AA was determined by LC-MS-MS by the CVUA according to the test procedure 201L01301 [49]. The eluates were separated by a graphite or RP18-phase and detected by tandem-mass-spectrometer. Quantification was undertaken by using the isotope- labelled internal standard (D3-Acrylamide).

\subsection{Statistical analysis}

Yield and quality data (crude protein, sedimentation value), as well as free Asn were subjected to analysis of variance (ANOVA) using the Procedure MIXED from the statistical software package SAS 9.1. (SAS Institute Inc., Cary, NC, USA). If necessary, data were ln- or square root-transformed, to stabilize normal distribution and homogeneity of variance. A comparison of means was accomplished using the t-Test.

ANOVA was done in two steps: In a first step, the main effects year, cropping system, crop species and interactions were investigated. In a second step, crop species were analysed separately for determining potential varietal differences depending on year and cropping system. For the parameter AA, no statistical analysis was undertaken. This was because only single samples from one field replicate were selected by the level of free Asn to represent the whole range from low to high for each species. 


\section{Results}

Grain yield, quality parameters and free Asn content of the three cereal species were significantly influenced by cropping system and year (Table 4). Additionally, the threefold interaction $\mathrm{CS} \times \mathrm{Y} \times \mathrm{S}$ was significant for all parameters except for the sedimentation value.

Table 4: F-values and p-values for main effects: cropping system (CS), species, year and interactions between factors on grain yield, crude protein content, sedimentation value and the Asn content of the flours

\begin{tabular}{lllllllllll}
\hline & & \multicolumn{2}{c}{ Grain yield } & \multicolumn{2}{c}{ Crude protein } & \multicolumn{2}{c}{ Sedimentation value } & \multicolumn{2}{l}{ Free Asn } \\
& DF & $\mathbf{F}$ & $\mathbf{p}$ & $\mathbf{F}$ & $\mathbf{p}$ & $\mathbf{F}$ & $\mathbf{p}$ & $\mathbf{F}$ & $\mathbf{p}$ \\
\hline CS & 1 & 101.92 & $* * *$ & 266.94 & $* * *$ & 15.41 & $* * *$ & 41.60 & $* * *$ \\
Species (S) & 2 & 40.77 & $* * *$ & 710.29 & $* * *$ & 118.62 & $* * *$ & 470.25 & $* * *$ \\
Year (Y) & 1 & 1.78 & 0.21 & 60.33 & $* * *$ & 0.65 & 0.42 & 52.01 & $* * *$ \\
CS $\times$ S & 2 & 1.79 & 0.17 & 69.49 & $* * *$ & 19.59 & $* * *$ & 7.29 & $* * *$ \\
CS $\times$ Y & 1 & 1.47 & 0.25 & 73.02 & $* * *$ & 0.05 & 0.82 & 0.02 & 0.89 \\
S $\times$ Y & 2 & 11.44 & $* * *$ & 1.83 & 0.16 & 4.46 & $*$ & 10.45 & $* * *$ \\
CS $\times$ S $\times Y$ & 2 & 8.53 & $* * *$ & 32.66 & $* * *$ & 0.13 & 0.71 & 14.89 & $* * *$ \\
\hline
\end{tabular}

Winter wheat (WW) and winter spelt (WS) grain yields were about 1.1 to $1.9 \mathrm{t} \mathrm{ha}^{-1}$ higher in the conventional system when compared to the organic cropping systems in both experimental years (Table 5). In contrast, conventionally produced winter rye only achieved higher yields when compared to the organic cropping system (by $2 \mathrm{t} \mathrm{ha}^{-1}$ ) in 2008. 
Table 5: Grain Yield (GY), quality parameters (crude protein [CP], sedimentation value [SV]), free Asn and AA formation potential) of the three tested species depending on cropping system and year. Treatments within the same species $(\mathrm{WW}=$ winter wheat, $\mathrm{WS}=$ winter spelt, $\mathrm{WR}=$ winter rye) assigned by the same letters are not significantly different $(\alpha=0.05$, $\mathrm{t}$ Test).

\begin{tabular}{|c|c|c|c|c|c|c|c|c|c|}
\hline & & $\begin{array}{l}\text { GY } \\
\text { t ha-1 } \\
\text { conventional }\end{array}$ & organic & $\begin{array}{l}\text { CP } \\
(\%) \\
\text { conventional } \\
\end{array}$ & organic & $\begin{array}{l}\text { SV } \\
(\mathrm{ml}) \\
\text { conventional }\end{array}$ & organic & $\begin{array}{l}\text { Asn } \\
\left(\mathrm{mg} 100 \mathrm{~g}^{-1} \mathrm{D}\right) \\
\text { conventional }\end{array}$ & organic \\
\hline \multirow[t]{2}{*}{ WW } & 2007 & $7.70 \mathrm{c}$ & $6.55 \mathrm{~b}$ & 14.18 c & 9.77 a & $37.00 \mathrm{~b}$ & $29.09 a$ & $16.07 \mathrm{c}$ & $12.67 \mathrm{~b}$ \\
\hline & 2008 & $7.01 \mathrm{~b}$ & $6.04 \mathrm{a}$ & $12.56 \mathrm{~b}$ & $9.66 \mathrm{a}$ & $40.47 b$ & $31.56 \mathrm{a}$ & $14.97 \mathrm{bc}$ & $7.89 \mathrm{a}$ \\
\hline \multirow[t]{2}{*}{ WS } & 2007 & $6.44 \mathrm{c}$ & $4.56 \mathrm{a}$ & $14.78 \mathrm{~b}$ & $14.46 \mathrm{~b}$ & $25.40 \mathrm{a}$ & $25.33 \mathrm{a}$ & $10.47 \mathrm{ab}$ & $12.24 \mathrm{~b}$ \\
\hline & 2008 & $6.75 \mathrm{c}$ & $5.50 \mathrm{~b}$ & $13.16 \mathrm{a}$ & $13.23 \mathrm{a}$ & $24.03 \mathrm{a}$ & $24.81 \mathrm{a}$ & $11.44 \mathrm{~b}$ & $8.62 \mathrm{a}$ \\
\hline \multirow[t]{2}{*}{ WR } & 2007 & $7.54 \mathrm{bc}$ & $7.22 \mathrm{~b}$ & $10.74 \mathrm{c}$ & $6.47 \mathrm{a}$ & & & $54.31 \mathrm{c}$ & $35.92 \mathrm{~b}$ \\
\hline & 2008 & $7.87 \mathrm{c}$ & $5.83 \mathrm{a}$ & $7.54 \mathrm{~b}$ & $7.35 \mathrm{~b}$ & & & $31.50 \mathrm{ab}$ & $30.14 \mathrm{a}$ \\
\hline
\end{tabular}


For both years crude protein content of winter wheat was significantly higher (2.5 to $4.5 \%$ ) under conventional conditions (Table 5). Additionally, a significant year-to-year effect was obvious. In contrast, crude protein content of spelt was not significantly affected by the production system, but by year, showing on average a $1.4 \%$ higher crude protein content in 2007. Crude protein contents of conventionally grown rye were only significantly higher in 2007.

Sedimentation values of winter wheat for both years were considerably higher under conventional growing conditions when compared to organic farming (Table 5). For spelt, no effect was observed for either years.

\section{Free Asn as main AA precursor}

Free Asn content was significantly affected by cropping system, species, year and the interaction between these effects (Table 4). Rye had the highest Asn contents in both cropping systems and for both years with on average about $38 \mathrm{mg} 100 \mathrm{~g}^{-1}$ flour-DM, followed by winter wheat with 13 and winter spelt with $11 \mathrm{mg} 100 \mathrm{~g}^{-1}$ flour-DM (Table 5). Averaged across the three species, organically produced grain contained about $26 \%$ lower Asn contents compared to conventional production. Differences between cropping systems were most distinctive in winter wheat, with $22-47 \%$ lower Asn contents under organic production depending on the year (Table 5). Asn contents of spelt and rye differed only significantly between the two cropping systems in single years (Table 5, Figure 1). Whilst Asn levels of spelt were not affected by the cropping system in 2007, organically produced spelt had a significantly lower Asn content of $8.6 \mathrm{mg} 100 \mathrm{mg}^{-1}$ flour-DM in 2008, which was about $25 \%$ lower than under conventional farming for the same year. However, spelt cultivars revealed to have significant effects on Asn levels irrespective of year and cropping system, with cultivars Frankenkorn and Schwabenkorn having the lowest and highest Asn contents (Franckenkorn: $7.5 \mathrm{mg}$ $100 \mathrm{mg}^{-1}$ flour-DM, Schwabenkorn: $13 \mathrm{mg} 100 \mathrm{mg}^{-1}$ flour-DM), respectively (Figure 1). In 2007, organically produced rye had significantly lower Asn contents while no significant differences in the Asn content occurred between the two cropping systems in 2008 (Table 5). By comparing the Asn response of the different cultivars in both cropping systems, four out of ten organically produced wheat cultivars had significantly lower Asn levels than their conventional counterparts. In 2007 and in 2008, Asn contents of each of the ten tested wheat cultivars were significantly lower under organic compared to conventional farming (Figure 1).

In 2007, cvs Privileg and Naturastar had the highest Asn contents of 26.6 and $24.5 \mathrm{mg} 100 \mathrm{~g}^{-1}$ under conventional conditions. All other conventionally grown cultivars had significantly lower

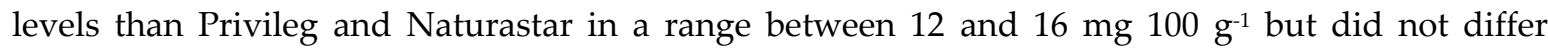
significantly from each other (Figure 1). Cultivars Privileg and Naturastar also showed the highest Asn contents under organic conditions (18.5 and $24.8 \mathrm{mg} 100 \mathrm{~g}^{-1}$ ), which were significantly higher than from organically produced cultivars Bussard, Achat, Batis, Astron and Magnus with Asn

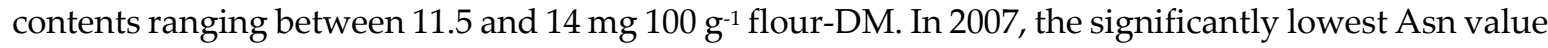
under organic farming was recorded for cultivar Ludwig with $6 \mathrm{mg}^{100 \mathrm{~g}^{-1}}$ followed by cultivar Capo with 9.1 and cultivar Akteur with $9.8 \mathrm{mg} 100 \mathrm{~g}^{-1}$ flour-DM (Figure 1). These three were the only

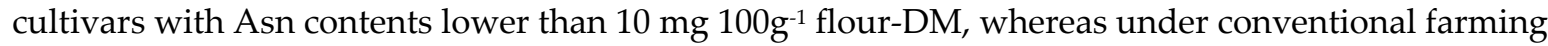
none of the tested cultivars had Asn contents below this level. Privileg and Naturastar were the cultivars with the highest Asn contents, as well as in 2008, under conventional farming. With levels of 31.6 and 32.1 they significantly outreached the levels of all other conventionally produced wheat

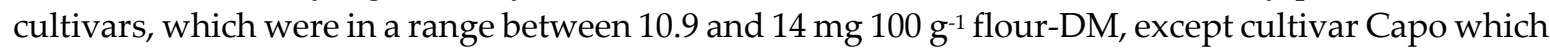

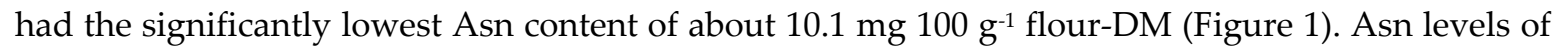
all organically grown cultivars were lower than $10 \mathrm{mg} 100 \mathrm{~g}^{-1}$ flour-DM, except for cultivar Privileg with $10.7 \mathrm{mg} 100 \mathrm{~g}^{-1}$ flour-DM. Cultivars Capo, Astron and Achat had the significantly lowest Asn contents of all organically produced wheat cultivars in 2008 with values of 6.1 and $6.5 \mathrm{mg} 100 \mathrm{~g}^{-1}$ flour-DM. 

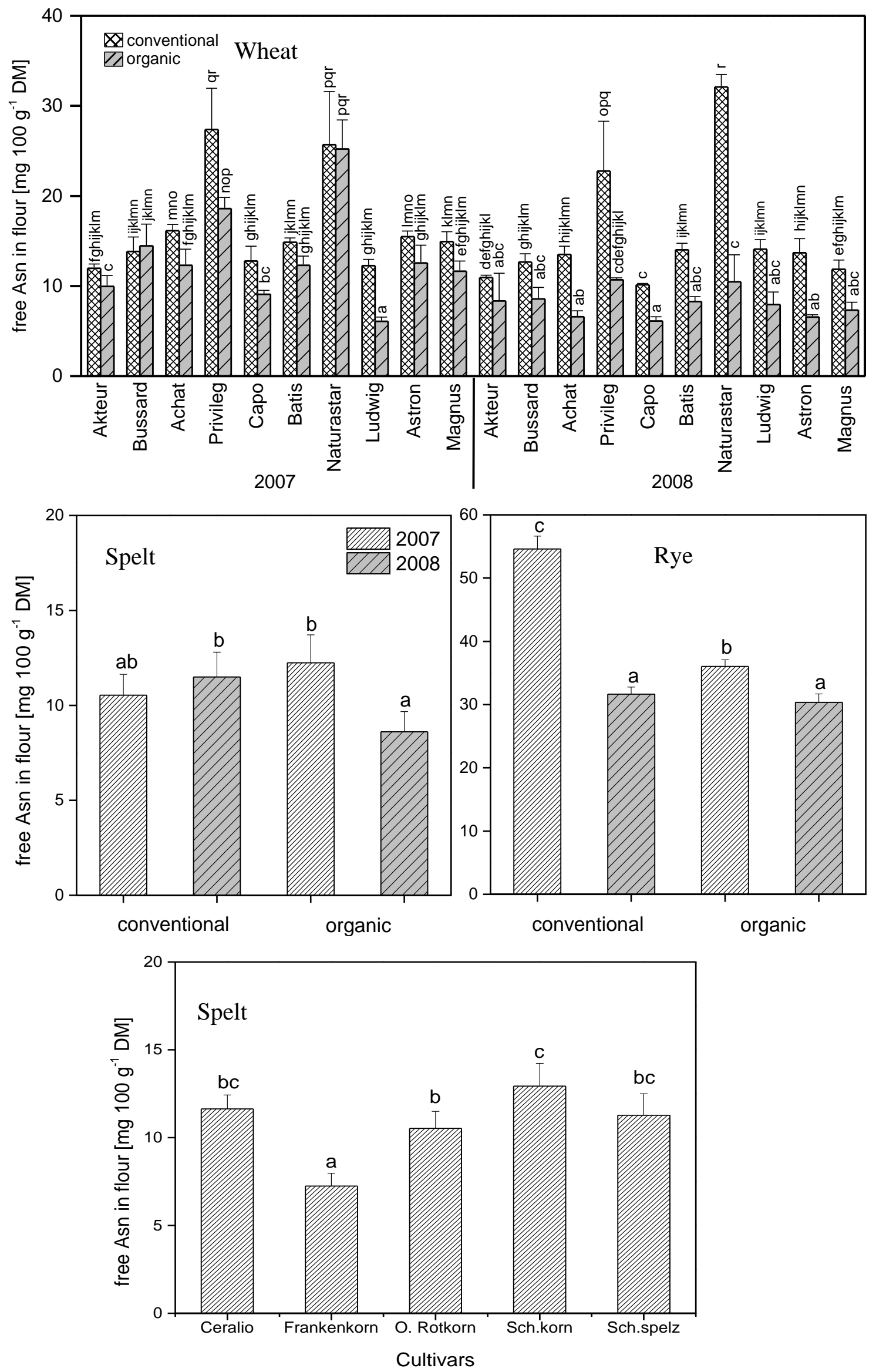
Figure 1: Free Asn content separated by species (wheat, spelt, rye), cropping system (organic, conventional), year $(2007,2008)$ and cultivars in dependence of their significant highest order interaction. Columns with different letters within cropping system and year indicate significant differences $(\alpha=0.05, \mathrm{t}$-Test)

\section{Correlation of crude protein, free Asn and $A A$}

Averaged over cultivars, wheat crude protein and Asn contents correlated well depending on cropping system and experimental year $\left(\mathrm{R}^{2}=0.71\right.$; Figure 2$)$. However, between different cultivars there was only a weak correlation of both parameters between different cultivars under both cropping practices in both years $\left(R^{2}=0.18^{* * *}\right.$, Figure 3$)$, meaning that cultivars with high crude protein contents did not show high Asn levels per se and vice versa. The correlation of crude protein and Asn of winter spelt was weak across the two cropping systems and years $\left(\mathrm{R}^{2}=0.1\right.$, data not shown) when averaged over cultivars, which was mainly due to a low variability of crude protein content between cropping systems and years. Crude protein content and Asn content of rye correlated well with a $\mathrm{R}^{2}=0.8$ (data not shown).

Wheat Asn contents and AA levels in heated flour samples correlated well with $\mathrm{R}^{2}=0.7$ for the organically produced samples and with $\mathrm{R}^{2}=0.6$ for the conventionally produced ones (data not shown).

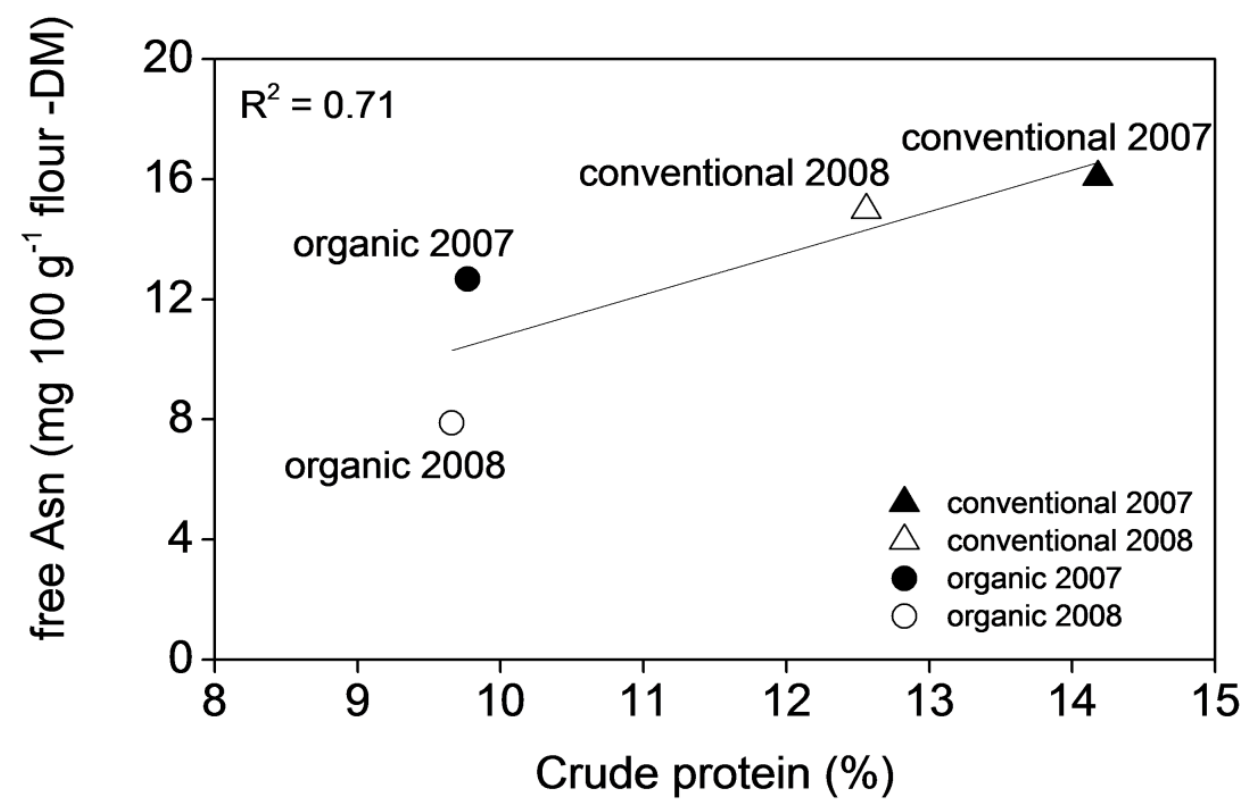

Figure 2: Correlation of crude protein content and Asn levels in wheat flours produced under organic and conventional farming conditions in 2007 and 2008 (means over cultivars). 


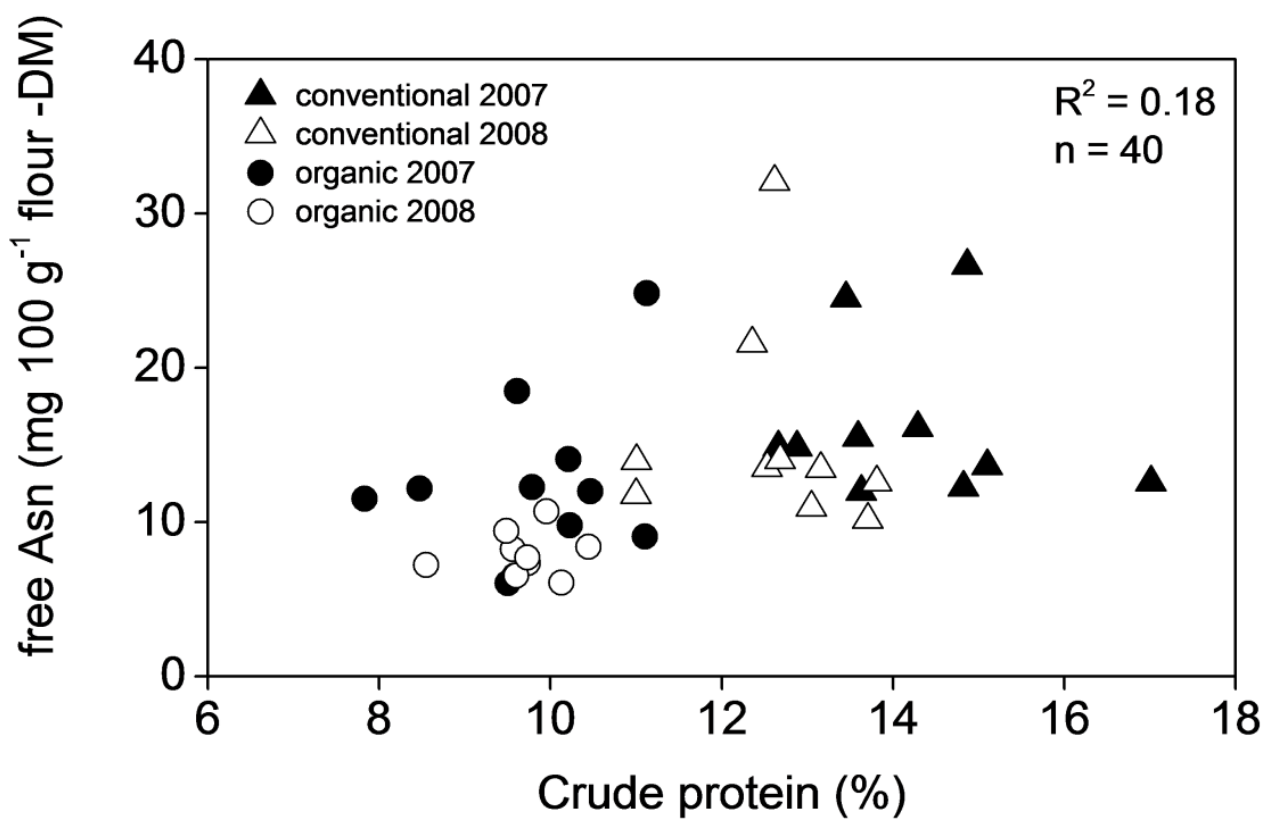

Figure 3: Relationship between crude protein content and free Asn levels in wheat flours produced under conventional and organic conditions in 2007 and 2008.

\section{Discussion}

Grain yield and baking quality

Grain yield of all three organically produced species was significantly lower compared to their conventionally grown counterparts. Organically grown wheat produced on average about $85 \%$ of the yield compared to conventionally gown. For spelt and rye the yield gap was even larger. Differences concerning grain yield of 20 to $30 \%$ between conventional and organic farming are described by other authors [4, 25, 31]. Determined lower protein contents of on average $3.5 \%$ across both years between conventionally and organically produced wheat corresponded well with results reported by Bilsborrow et al. [5] from a long-term field trial in the UK. Both difference in yield and crude protein content were most likely the result of differences in the availability of plant-available nitrogen between the two cropping systems as shown by other authors [5,32]. Especially nitrogen availability influences grain yield [38] and crude protein content [46], which is an important quality parameter for baking quality of wheat due to its strong correlation with bread volume. Nitrogen fertilizer amounts in conventional farming are usually higher, mineral nitrogen is available faster than organic nitrogen. Thus, mineral nitrogen in conventional farming can be directed more precisely, leading to a higher grain yields. Under organic conditions there is often a mismatch between the plant-nitrogen demand and the mineralisation rate depending on environmental conditions e.g. temperature and soil moisture [35]. Moreover, higher weed, pest and disease pressure could also have been responsible for yield differences, but were not assessed in our experiment as measures to control them under organic farming are very limited. Moreover, site-specific conditions usually strongly affect yield more than weeds, pests and diseases when crops are grown organically [27]. Thus, the manifold regulatory options in conventional cropping systems can compensate for location deficits better, leading to higher grain yields [3]. Consequently, if organically produced bakery goods are demanded, lower yields and lower baking qualities must be accepted [19] and bread bakery processing has to be adjusted to the lower protein contents of such flours [21] to achieve acceptable products.

However, the postulated levels of protein needed by industry are under discussion as there are some studies announcing, that good baking quality of e.g. wheat flour doesn't need high levels of crude protein [37]. Much more important are gluten content and gluten quality. Thus, wheat cultivar cultivated under organic farming conditions can offer a good baking quality while having lower protein content. 
No significant difference of spelt crude protein content between the two cropping systems could be observed. This was presumably due to only minor differences in nitrogen fertilizer amounts and nitrogen availability especially in the latter phase of grain filling.

Free Asn

Free Asn is the critical factor for acrylamide formation during processing of cereal based bakery products [9] and Asn contents in flour correlate almost linearly with the acrylamide content in heated flour [13] or in breads [8]. Free asparagine also proved to be strongly correlated with the AA formation in heated flour samples in our study. Rye Asn contents were considerably higher than that of wheat and spelt. This corresponds well with findings from Fredriksson et al. [18], Elmore et al. [16] and Claus et al. [8] who found up to 3 or 4 times higher Asn levels in rye compared to wheat or spelt. Therefore, the acrylamide formation potential of bakery goods made from rye flour is considered to be higher than from wheat or spelt $[8,16]$. In contrast studies by Curtis et al. [13] showed that AA formation in heated flour per unit Asn was much lower in rye than in wheat flour, suggesting that the higher Asn level compared to wheat does not inevitably mean that rye has a higher AA formation potential per se.

The amount of free Asn was strongly affected by the cropping system. Across all species, free Asn was $26 \%$ lower under organic conditions. Differences in the Asn level between the cropping systems were consistent across both experimental years for wheat, whereas spelt and rye showed inconsistencies. Organically produced wheat had a lower Asn content of about 44\% compared to conventional production when averaged over years and cultivars, whereas Asn contents of organically produced spelt and rye were lower only in single years. Therefore, organically produced wheat particularly offers the opportunity to significantly lower the AA potential of bread and bread rolls via choosing a raw material low in free Asn. Weber et al. [46] investigated the impact of different nitrogen amounts and timings on the resulting Asn levels in flours from a conventionally produced winter wheat cultivar. They found a close correlation between crude protein and Asn content. Furthermore, it was predominantly the 'late applied nitrogen' that led to crude protein contents of more than $13 \%$ which significantly increased free Asn compared to the unfertilized control [46]. Winkler and Schön [50] found a close correlation between nitrogen concentration and free Asn in barley grain, as well as Curtis et al. [13] found in rye grain. As nitrogen fertilization in conventional farming is usually applied at higher amounts, and availability of mineral nitrogen is also higher than found in organically applied nitrogen, the higher level of free Asn under conventional farming presumably resulted from the differences in the nitrogen supply and availability between both systems during the phase of grain filling. This hypothesis is strongly supported by the close correlation between wheat crude protein contents of the two cropping systems and years and the Asn contents in flour, when averaged across cultivars.

In general, winter spelt and winter rye have a lower $\mathrm{N}$-demand compared to wheat. This led to a smaller difference in the crude protein contents within the two species between the conventional and organically grown grains. Thus, this may explain the less pronounced impact of the cropping system on the Asn contents within winter spelt and winter rye in a single year. Springer et al. [39] found higher amounts of Asn in organically produced cultivars compared to those conventionally produced. They assumed that the higher share of the seed coat on the grain under organic cultivation might have been responsible for the higher contents of Asn found in the organically cropped cultivars. This effect could not be observed in our study. Nevertheless, as reported by Corol et al [11], wholemeal flour, can reach higher levels of free Asn in a range of up to 32 to $156 \mathrm{mg} 100 \mathrm{~g}^{-1}$ which is about 6 to 10-fold above our reported results within wheat flour.

Cultivars owning a high baking quality do not inevitably have to be linked with high Asn contents and ultimately a high AA formation potential. This is suggested by the weak correlation found between crude protein and free Asn contents of different wheat cultivars. Furthermore, the results showed that cultivars combining high or acceptable baking quality and low Asn contents are already available, and that the AA formation potential could further be lowered by selecting and 
cultivating appropriate cultivars, irrespective of cropping system, if the information on genotypic disposition regarding Asn accumulation would be available.

However, it has to be considered, that environment (= location and year) can affect Asn levels considerably, as also shown by Curtis et al. [12] for wheat and by Curtis et al. [13] for rye. But up to now information on how soil type, temperature and precipitation affect grain-Asn accumulation is missing [28]. Within wheat genotypes grown at six locations in Europe, Corol et al. [11] described, that only $13 \%$ of the free Asn variability was explainable by heritability while about $36 \%$ was caused by environment. This must be also taken into account for the interpretation of our data, as the locations for the conventional and for the organic trial were located within a distance of $20 \mathrm{~km}$. Therefore, cultivars must be tested at different locations for at least two years before recommendations or selection of cultivars can be announced for further specific breeding programs targeted towards lowering the AA precursor contents.

\section{Conclusions}

The study aimed to assess the effect of organic versus conventional farming practices on free Asn contents in flours of winter wheat, winter spelt and winter rye. The cropping system significantly affected Asn levels. The effect was most noticeable and consistent for winter wheat, where Asn levels were lowered on average by $33 \%$ if cultivars were organically grown. Organically grown spelt and rye showed lower Asn contents only in single years. Different intensities of plant-available nitrogen during critical phases of grain development between both systems are considered to be mainly responsible for differences in Asn accumulation. These differences were most evident for wheat due to its high $\mathrm{N}$ demand and the close correlation between nitrogen supply and baking quality. Therefore, organically produced wheat flour can be well regarded as having a lower AA formation potential than conventionally produced wheat, despite also having lower yields. Furthermore, the weak correlation between crude protein and Asn content between different cultivars suggested that choice and cultivation of cultivars combining low Asn contents with adequate baking quality can help in lowering the amount of dietary AA intake from cereal based bakery goods, irrespective if the raw material originates from organic or conventional farming. Especially low-Asn cultivars with response high stability over different environments are of great interest for future research in this area.

\section{References}

1. Amrein, T.M., Schönbächler, B., Rohner, F., Lukac, H., Schneider, H., Keiser, A., Escher, F., Amadò, R. Potential for acrylamide formation in potatoes: Data from the 2003 harvest. Eur. Food Res. Technol. 2004, 219, 572-578, DOI 10.1007/s00217-004-1025-z.

2. Baeckstrom, G., Hanell, U., Svensson, G. Baking quality of winter wheat grown in different cultivating systems 1992-2001 - a holistic approach. Journal of Sustainable Agriculture 2004, 3, 63-83. DOI 10.1300/J064v24n01_06.

3. Beckmann, U., Grünbeck, A., Hänsel, M., Karalus, W., Kolbe, H., Schuster, M., Arp, B., Beese, G., Krelling, B., Pöliz, B., Auerbach, D. Getreide im ökologischen Landbau. Informationen für Praxis und Beratung. http://orgprints.org/15102/4/Getreidearten.pdf 2001, (Zugriff: 24. März 2010).

4. Beste, A. Ökologischer Landbau - wie er funktioniert und was er leisten kann? In: Ökologischer Landbau und regionale Vermarktungsstrategien - eine Chance für Klimaschutz und Beschäftigung. Arbeitspapier 26, 2000, Hans Böckler Stiftung, Düsseldorf, Hrsg.: Spieß-Wallbaum, Zepf, Bockelmann. http://www.gesundeerde.net/pdfdateien /\%D6L\%20Boeckler.pdf (Zugriff: 19. April 2010).

5. Bilsborrow, P.; Cooper, J.; Tetard-Jones, C.; Srednicka-Tober, D.; Baranski, M.; Eyre, M.; Schmidt, C.; Shotton, P.N. The effect of organic and conventional management on the yield and quality of wheat grown in a longterm field trial. European Journal of Agronomy 2013, 51, 71-80. DOI 10.1016/j.eja.2013.06.003.

6. Capuano, E., Ferrigno, A., Acampa, I., Serpen, A., Acar, Ö.C., Gökmen, V., Fogliano, V. Effect of flour type on Maillard reaction and acrylamide formation during toasting of bread crisp model systems and mitigation strategies. Food research International 2009, 42, 1295-1302, DOI 10.1016/j.foodres.2009.03.018. 
7. Ciesarova, Z., Kukurova, K., Bednarikova, A., Morales, F.J. Effect of heat treatment and dough formulation on the formation of Maillard reaction products in fine bakery products - benefits and weak points. J. of Food and Nutrition Research 2009, 48 (1), 20-30.

8. Claus A., Schreiter P., Weber A., Graeff S., Herrmann W., Claupein W., Schieber A., Carle R. Influence of Agronomic Factors and Extraction Rate on the Acrylamide Contents in Yeast-Leavened Breads. J. of Agric. and Food Chem. 2006, 54, 8976-8976, DOI 10.1021/jf061936f.

9. Claus, A., Carle, R., Schieber, A. Acrylamide in cereal products: A review. J. of Cereal Science 2008, 47, 118133, DOI 10.1016/j.jcs.2007.06.016.

10. Commission Regulation (EU) 2017/2158. Establishing mitigation measures and benchmark levels for the reduction of the presence as acrylamide in food. J. of the European Union 2017, Volume 60, 2017, 24-44.

11. Corol, D.I., Ravel, C., Rakszegi, M., Charmet G., Bedo, Z., Beale M.H., Shewry P.R., Ward, J.L. ${ }^{1}$ H-NMR screening for the high-throughput determination of genotype and environmental effects on the content of asparagine in wheat grain. Plant Biotechnology Journal 2016, 14, 128-139, DOI 10.1111/pbi.12364.

12. Curtis T.Y., Muttucumaru N., Shewry P.R., Parry M.A.J., Powers S.J., Elmore J.S., Mottram D.S., Hook S., Halford N.G. Effects of Genotype and Environment on Free Amino Acid Levels in Wheat Grain: Implications for Acrylamide Formation during Processing. J. of Agric. and Food Chem. 2009, 57, 1013-1021, DOI 10.1021/jf8031292.

13. Curtis, T.Y., Powers, S.J., Balagianis, D., Elmore, J.S., Mottram, D., Parry, M.A.J., Rakszegi, M., Bedo, Z., Shewry, P.R., Halford, N.G. Free Amino Acids and Sugars in Rye Grain: Implications for Acrylamide Formation. J. of Agric. and Food Chem. 2010, 57, 1013-1021, DOI 10.1021/jf903577b.

14. Delatour, T., Perisset, A., Goldmann, T. Improved sample preparation to determine acrylamide in difficult matrixes such as chocolate powder, cocoa, and coffee by liquid chromatography tandem mass spectrometry. J. Agric. Food Chem. 2004, 52, 4625-4639, DOI 10.1021/jf0498362.

15. Dumas, A. Stickstoffbestimmung nach Dumas. Die Praxis des org. Chemikers, 41th ed. Schrag, Nürnberg 1962.

16. Elmore, J.S., Koutsidis, G., Dodson, A.T., Mottram, D.S., Wedzicha, B.L. Measurement of acrylamide and its precursors in potato, wheat, and rye model systems. J. Agric. Food Chem. 2005, 53, 1286-1293, DOI: 10.1021/jf048557b.

17. European Food Safety Authority: Results on Acrylamide levels in food from monitoring yeas 2007-2009 and exposure assessment. EFSA J. 2011, 9, 2133.

18. Fredriksson, H., Tallving, J., Rosen, J., Aman, P. Fermentation Reduces free Asparagines in Dough and Acrylamide Content in Bread. Cereal Chemistry 2004, 81 (5), 650-653. DOI 10.1094/CCHEM.2004.81.5.650.

19. Gooding, M. J., Davies, W. P., Thompson, A. J., Smith, S.P. The challenge of achieving breadmaking quality in organic and low input wheat in the UK-A review. Aspects of Applied Biology 1993, 36, 189-198.

20. Granvogl M., Wiesner H., Koehler P., Von Tucher S., Schieberle P. Influence of Sulfur Fertilization on the Amounts of Free Amino Acids in Wheat. Correlation with Baking Properties as well as with 3Aminopropionamide and Acrylamide Generation during Baking. J. of Agric. and Food Chem. 2007, 55, 42714277, DOI 10.1021/jf0702621.

21. Haglund, A., Johansson, L., Dahlstedt, L. Sensory evaluation of wholemeal bread from ecologically and conventionally grown wheat. J. of Cereal Science 1998, 27,199-207.

22. Hedegaard, R.V., Granby, K., Frandsen, H., Thygesen, J., Skibsted L.H. Acrylamide in bread. Effect of prooxidants and antioxidants. Eur Food Res Technol. 2008, 227, 519-525, DOI 10.1007/s00217-007-0750-5.

23. Johansson E., Svensson G. Variation in bread-making quality: effects of weather parameters on protein concentration and quality in some Swedish wheat cultivars grown during the period 1975-1996. J. of the Science of Food and Agriculture 1998, 78, 109-118, DOI 10.1002/(SICI)1097-0010(199809)78:1<109::AIDJSFA92>3.0.CO;2-0.

24. Konings, E.J.M., Hogervorst, J.G.F., Van Rooij, L., Schouten, L.J., Sizoo, E.A., Van Egmond, H.P., Goldbohm, R.A., Van Den Brandt, P.A. Validation of a database on acrylamide for use in epidemiological studies. European Journal of Clinical Nutrition 2010, 64, 534-540. DOI 10.1038/ejcn.2010.17.

25. Konvalina, P., Moudry jr., J., Capuchova, I., Moudry, J. Baking quality of winter wheat varieties in organic farming. Agronomy Research 2009, (Special Issue II) (7), S. 612-617.

26. Kotsiou, K., Tasioula-Margari, M., Capuano, E., Fogliano, V. Effect of standard phenolic compounds and olive oil phenolic extracts on acrylamide formation in an emulsion system. Food Chemistry 2011, 124, 242247. DOI 10.1016/j.foodchem.2010.06.025. 
27. Köpke, U. (2000): Ökologischer Landbau. In: Entrup, N. L., Oehmichen, J.: Lehrbuch des Pflanzenbaues Band 2: Kulturpflanzen. Verlag Th. Mann, Gelsenkirchen. S. 772-819. ISBN 978-3981057584.

28. Lea P.J., Sodek L., Parry M.A.J., Shewry P.R., Halford N.G. Asparagine in Plants. Annals of Applied Biology 2006, 150, 1-26. DOI:10.1111/j.1744-7348.2006.00104.x.

29. Lüpke, M. Entwicklung und Anwendung von Reagenzien und Verfahren zur achiralen und chiralen Analytik von Aminosäuren mittels GC und HPLC. Dissertation, Universität Hohenheim 1996.

30. Martinek, P., Klem, K., Váňová, M., Bartáčková, V., Večerková, L., Bucher, P., Hajšlová, J. Effects of nitrogen nutrition, fungicide treatment and wheat genotype on free asparagine and reducing sugars content as precursors of acrylamide formation in bread. Plant Soil Environ. 2009, 55, (5), 187-195.

31. Mäder, P., Fließbach, A., Dubois, D., Gunst, L., Fried, P., Niggli, U. Bodenfruchtbarkeit und biologische Vielfalt im ökologischen Landbau. In: Ökologie \& Landbau 2002, 124/4, 12-16.

32. Mäder, P., Hahn, D., Dubois, D., Gunst, L., Alföldi, T., Bergmann, H., Oehme, M., Amado ', R., Schneider, H., Graf, U., Velimirov, A., Fließbach, A., Niggli, U. Wheat quality in organic and conventional farming: results of a 21 year field experiment. Journal of Science of Food and Agriculture 2007, 87, 1826-1835. DOI 10.1002/jsfa.2866.

33. Mottram, D.S, Wedzicha, B.L., Dodson, A.T. Acrylamide is formed in the Maillard reaction. Nature 2002, 419, 448-449.

34. Muttucumaru N., Halford N.G., Elmore J.S., Dodson A.T., Parry M., Shewry P.R., Mottram D.S. Formation of High Levels of Acrylamide during the Processing of Flour Derived from Sulfate-Deprived Wheat. J. of Agric. and Food Chem. 2006, 54, 8951-8955, DOI 10.1021/jf0623081.

35. Pang, X.P., Lettey, J., Challenges of timing nitrogen availability to crop nitrogen requirements. Soil Science of America Journal 2000, 64, 247-253.

36. Postles, J., Powers S.J., Elmore, J.S., Mottram, D.S., Halford N.G. Effects of variety and nutrient availability on the acramamide-forming potential of rye grain. J. of Cereal Science 2013, 57, 463-470, DOI 10.1016/j.jcs.2013.02.001.

37. Schachschneider, R. Backqualität von Winterweizen - Ärger mit dem Proteingehalt. Getreidemagazin 3/2011.

38. Sieling, K. (2008): Nährstoffbedarf In: Hanus, H., Heyland, K.-U., Keller, E. R.: Getreide und Futtergräser (Handbuch des Pflanzenbaus - Band 2). Verlag Eugen Ulmer, Stuttgart. S. 103-104. ISBN 978-3800132003.

39. Springer, M., Fischer, T., Lehrack, A., Freund, W. Acrylamidbildung in Backwaren. Getreide, Mehl und Brot 2003, 57, 274-278.

40. Stadler, R.H., Blank, I., Varga, N., Robert, F., Hau, J., Guy, P.A., Robert, M.C., Riediker, S. Acrylamide from Maillard reaction products. Nature 2002, 419, 449-450.

41. Stockmann, F., Weber, E.A., Graeff, S., Claupein, W. Influence of cropping systems on the potential formation of acrylamide in different cultivars of wheat. 16th IFOAM Organic World Congress, Modena, Italy, June 16.20. 2008, http://orgprints.org/11975/.

42. Surdyk, N.; Rosen, J.; Andersson, R.; Åman, P. Effects of asparagine, fructose, and baking conditions on acrylamide content in yeast-leavened wheat bread. J. Agric. Food Chem. 2004, 52, 2047-2051, DOI 10.1021/jf034999w.

43. Taeymans, D., Wood, J., Ashby, P., Blank, I., Studer, A., Stadler, R.H., Gondé, P., Van Eijck, P., Lalljie, S., Lingnert, H., Lindblom, M., Matissek, R., Müller, D., Tallmadge, D., O’Brien, J., Thompson, S., Silvani, D., Whitmore, T. A Review of acrylamide: An industry perspective on research, analysis, formation, and control. Crit. Rev. Food Sci. Nutr. 2004, 44, 323-347, DOI 10.1080/10408690490478082.

44. Teller, G.L. Non-protein nitrogen compounds in cereals and their relation to the nitrogen factor for protein in cereals and bread. Cereal Chemistry 1932, 9, 261-274.

45. Wakaizumi, M., Yamamoto, H., Fujimoto, N., Ozeki K. Acrylamide degradation by filamentous fungi used in food and beverage industries. J. of Biosci. and Bioeng. 2009, 108 (5), 391-393, DOI 10.1016/j.jbiosc.2009.05.004.

46. Weber E.A., Graeff S., Koller W.D., Hermann W., Merkt N., Claupein W. Impact of nitrogen amount and timing on the potential of acrlyamide formation in winter wheat (Triticum aestivum L.). Field Crop Research 2008, 106, 44-52, DOI 10.1016/j.fcr.2007.10.011.

47. Weisshaar, R. Acrylamid in Backwaren - Ergebnisse von Modellversuchen. In: Deutsche LebensmittelRundschau 2004, (100), S. 92-97.

48. Weisshaar, R. Bestimmung von Acrylamid in Lebensmitteln, Aufarbeitungsverfahren für die LC-MS-MS. Prüfverfahren: 200L05401. 2003, Chemisches und Veterinäruntersuchungsamt Stuttgart, Germany. 
49. Weisshaar, R. Bestimmung von Acrylamid in Lebensmitteln, Prüfverfahren: 201L01301. 2003, Chemisches und Veterinäruntersuchungsamt Stuttgart, Germany.

50. Winkler, U., Schön, W.J. Amino acid composition of the kernel proteins in barley resulting from nitrogen fertilization at different stages of development. Journal of Agronomy and Crop Science 1980, 149, 503-512. 